\title{
Response of the Nordenskiöld Land (Spitsbergen) glaciers Grumantbreen, Håbergbreen and Dryadbreen to the climate warming after the Little Ice Age
}

\author{
Wieslaw ZIAJA \\ Institute of Geography and Spatial Management, Jagiellonian University, Gronostajowa 7, PL-30-387 Kraków, Poland \\ E-mail:w.ziaja@uj.edu.pl
}

\begin{abstract}
Three receding glaciers on Spitsbergen were examined on the basis of a 1936 topographic map and field investigations during the summers of 1995 and 2001. Håbergbreen, the largest glacier, has undergone the most intensive recession due to its relatively low altitude. There are two important manifestations of glacial recession: (1) the retreating glaciers leave rocky outcrops in the upper or steeper mountain slopes, and (2) the edges of moving glacier tongues are being transformed into motionless icecored moraines in valleys. The glaciers under study have not been transformed into rock glaciers. The recession rate has been increasing since 1995, which can be interpreted as a result both of positive feedback initiated by 20th-century climate warming and of slight warming in the 1990s. The glaciers have not thawed enough in relation to the warming and rise of the equilibrium-line altitude (by at least $250-300 \mathrm{~m}$ since the beginning of the 20th century). Håbergbreen, already split up into four ice patches, will disappear without a sustained temperature decrease during the next few decades. Grumantbreen and Dryadbreen will survive as small mountain glaciers if winter snow precipitation does not increase.
\end{abstract}

\section{INTRODUCTION}

The glaciers Grumantbreen, Håbergbreen and Dryadbreen are situated $10-15 \mathrm{~km}$ southwest of Longyearbyen and Adventfjorden, in Nordenskiöld Land, Spitsbergen (Fig. 1). They stretch from west to east in the northern slopes of the Lindströmfjellet-Håbergnuten mountain ridge, running inland to approximately $12 \mathrm{~km}$ from the coast of the inner Isfjorden, the widest Spitsbergen fjord. Dryadbreen constitutes the headwater section of the Fardalen river basin, and the two other glaciers the headwater section in Bjørndalen.

Nordenskiöld Land, and especially the part of it that borders Isfjorden, is the warmest and least glacierized region of Svalbard. Glaciers cover $18 \%$ of the area in the map sheet Adventdalen (Sørbel and others, 2001), but the superficial glaciation in the land between Adventfjorden and Colesdalen, which includes the glaciers under study, is much smaller at present, at roughly $10 \%$ of the area.

Small glaciers are usually sensitive to climatic changes. They had their maximum extent during the Little Ice Age (LIA). The final cold phase of the LIA occurred in the 1890s, with a decrease in mean annual temperature to $-9^{\circ} \mathrm{C}$ in west-central Spitsbergen (Brázdil, 1988). In comparison with the LIA, the whole of the 20th century was a warm period regardless of cold intervals during the 1940s and especially the 1960s (Fig. 2) (Brázdil, 1988; Hanssen-Bauer and others, 1990; Nordli, 1990; Førland and others, 1997). The mean annual temperature in west-central Spitsbergen during the last two decades of the 20th century was $3-4^{\circ} \mathrm{C}$ higher than in the 1890 s (Fig. 2). According to Førland and others (1997), there was probably no significant change in winter precipitation during the 20th century. J. Kohler and others (unpublished information) recognized a long-term trend toward increasing precipitation (by about $0.5 \mathrm{~mm} \mathrm{a}^{-1}$ over 90 years) for Svalbard Airport. However, this increase was not a significant obstacle to the recession of the glaciers under study, situated $12-13 \mathrm{~km}$ from the airport. The mean annual precipitation was $\sim 200 \mathrm{~mm}$ at Svalbard Airport on Adventfjorden in the period 1988-2000 (Statistics Norway, 2001). The glaciers under study have receded persistently since the beginning of the 20th century. The prevailing winds are from the southeast and east, except during the summer when westerly and southwesterly winds prevail (Hanssen-Bauer and others, 1990). The wind regime would not explain any difference in recession between the glaciers, as their exposure to winds is similar due to their northern aspect. None of the glaciers has been seen to surge in spite of their proximity to the town of Longyearbyen. Hence, the increase in temperature seems to be the main climatic process affecting glacial recession.

There is a lack of field data concerning the mass balance, total ice thickness and ice velocities of all the glaciers, so their dynamic response can only be commented on in a very general way. The manner and rate of recession is similar for all three glaciers. The recession has caused rapid changes in the landscape. These are the main topics of this paper.

\section{MATERIAL AND METHODS}

A topographic map at 1:100000 scale (current for 1936) and oblique black-and-white aerial photographs from 1936 (Norsk Polarinstitutt) allowed a precise delimitation of the glaciers' extent in 1936.

Field mapping of the northern slopes of the Lindströmfjellet-Håbergnuten mountain ridge was carried out in summer 1995 at 1:25000 scale (using the topographic map enlarged by four times). Particular attention was paid both to those areas abandoned by glaciers in the 20th century and to the most diminished glaciers. Vertical infrared aerial photographs at 1:15000 scale from 1990 (from Norsk Polarinstitutt) were also helpful in the mapping.

The same area was reinvestigated in 2001. All changes that had occurred within the glaciers and in their neighbourhood since 1995 were mapped. 


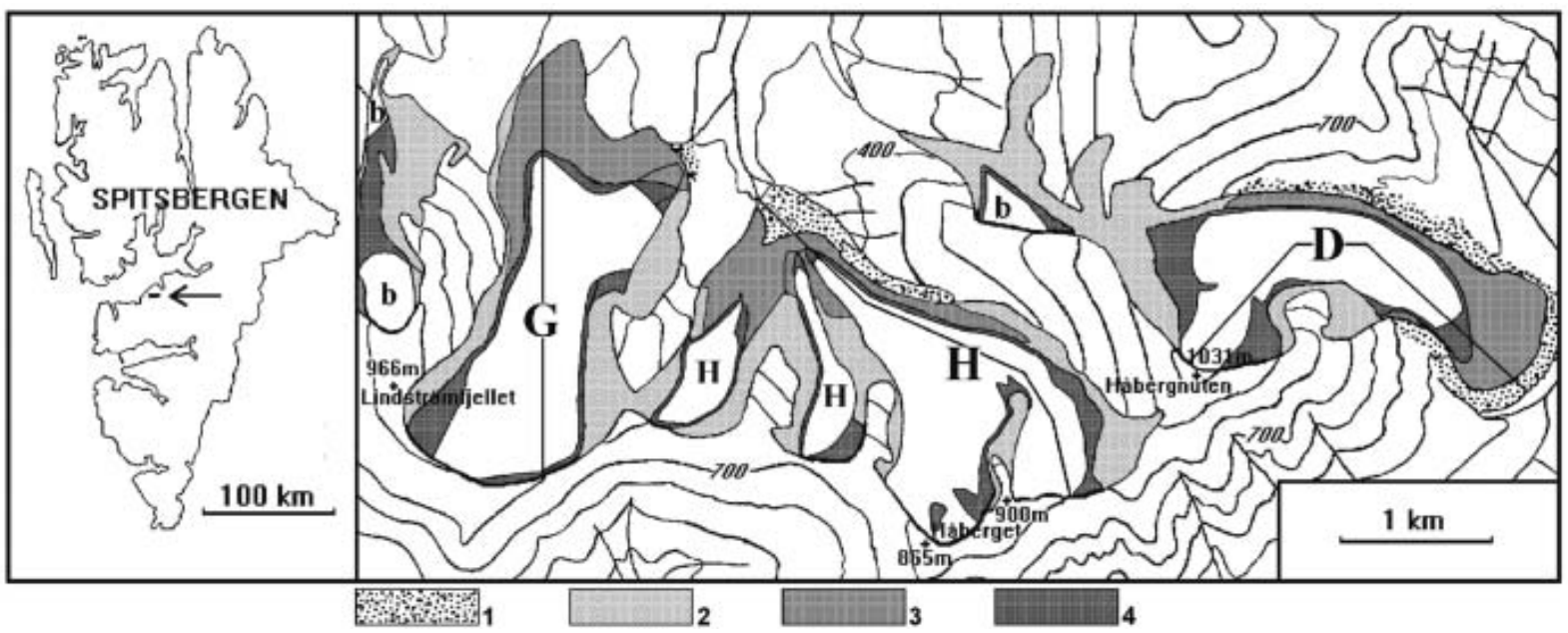

Fig. 1. Area of investigations: location, topography and glacial recession (apart from the westernmost outskirts). 1. Front and lateral moraines formed between the end of the Little Ice Age and 1936; 2. slopes abandoned by glaciers, 1936-95, leaving bedrock exposures without morainic cover; 3. ice-cored moraines as a result of deglaciation, 1936-95; and 4. areas abandoned by glaciers, 1995-2001. White areas indicate the extent of the glaciers in 2001: unnamed (b), Dryadbreen (D), Grumantbreen (G) and Håbergbreen (H).

A survey of the glaciers (altitude, width and length) was made and the new elevation contour lines within them drawn, for both 1995 and 2001. This was useful for determining the equilibrium-line altitude (ELA) by the Hess method, i.e. based on the inflection of the elevation contour lines on the topographic maps (Leonard and Fountain, 2003) for each glacier in both years. However, the results were verified by determining the ELA again as a snow-line at the end of the melting period because the shapes of the contour lines had became nebulous due to thinning of the glaciers by 1995 and 2001. A Paulin altimeter and also, in 2001, the global positioning system (GPS) were used to measure altitude. The measurements by the Paulin altimeter were exact to $5 \mathrm{~m}$ in 1995. A combination of two altitude measurement methods, the Paulin altimeter and GPS working in autonomous mode (not differential GPS), gave at least the same level of accuracy in 2001. The altitude data were compared and calibrated against altitudes of precisely determined topographic points. The measurements along the profile lines (Fig. 3) were repeated two or three times in 1995 and 2001. Differences between the measurements were very small, from 0 to $2-3 \mathrm{~m}$.
The area of the glaciers in 1936 was measured on the 1:100000 topographic map. Hagen and others (1993) measured the area by planimetry. The author repeated the computation manually using tracing (millimetre) graph paper, and obtained values about $9 \%$ higher. The $9 \%$ difference shows the size of the error in the measurements and does not change the conclusions. The values for 1936 from Hagen and others (1993) were used for the following analysis.

\section{RESULTS AND EVALUATION}

The area of the three valley glaciers decreased by $35 \%$ during the period $1936-95$, or by $0.6 \%$ per year on average. The rate of the superficial recession was similar in each glacier. From 1995 to 2001, the area covered by the glaciers decreased by $25 \%$, or $4.2 \%$ per year on average. Hence, the average annual rate of surface glacial recession between 1995 and 2001 was seven times higher than in the period 1936-95. However, that does not mean that recession began to accelerate in 1995. There were some differences in the rates at which the glaciers receded in the period 1995-2001 (Table 1).

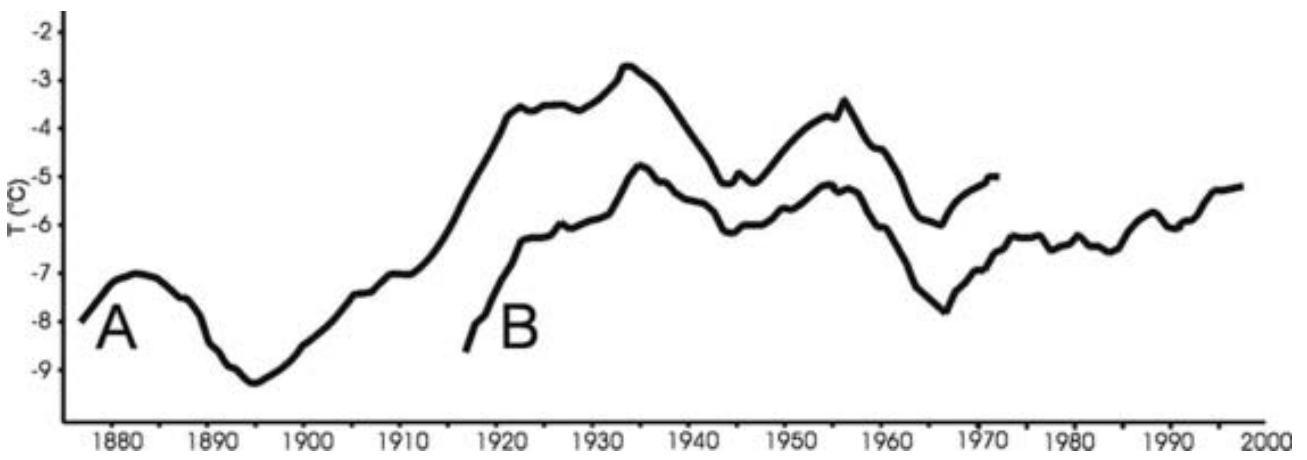

Fig. 2. Course of mean annual air temperature at west-central Spitsbergen smoothed by 10 year running averages. Curve A shows data for the periods 1873-1912 from V.S. Markin, based on measurements from different places, and 1913-72 from the Norwegian station Isfjord Radio (Brázdil, 1988). Curve B shows data for the period 1912-98 from the Norwegian Meteorological Institute at Svalbard Airport. Svalbard Airport station was established in 1975; the data for 1912-75 were obtained by statistical remodelling of meteorological series from Green Harbour, Longyearbyen and Isfjord Radio (Hanssen-Bauer and others, 1990). 
The decrease in the glaciers' surface area has been accompanied by a huge reduction in volume in the 20th century, indicated by a decrease in thickness. The size of the decrease between 1995 and 2001 was in general similar to that in the period 1936-95 (Fig. 3). The ELA rose from $\sim 500-550 \mathrm{~m}$ in 1936 to at least $650-700 \mathrm{~m}$ in 1995 (Ziaja, 2001) and $\geq 750 \mathrm{~m}$ in 2001.

Grumantbreen and Dryadbreen, situated respectively in the east and west of the Lindströmfjellet-Håbergnuten mountain ridge, underwent recession without fragmenting, whereas Håbergbreen, the most extensive glacier in the central part of the study area, split up into four small glaciers (Fig. 4). The two westernmost of these (Fig. 5) were found below the 1995 ELA, reaching up to only $700 \mathrm{~m}$. The two easternmost parts were probably still active but very thin in their highest parts, reaching up to $900 \mathrm{~m}$ in 1995.

The ice surface of the glaciers was fissured but did not show any holes formed by the collapse of internal glacial channels in 1995.

During 1995-2001 all the parts of Håbergbreen underwent regular recession from each side (Fig. 1). The thickness of dead parts below 500 ma.s.l. decreased by $\sim 10 \mathrm{~m}$. Meanwhile there were no changes in thickness above $700 \mathrm{~m}$ in the easternmost part, due to an increase in snow accumulation. The parts between 520 and $560 \mathrm{~m}$ of the still active tongue did not change, due to damming by the dead ice below. The most significant thinning, $\sim 20 \mathrm{~m}$, took place in the middle part (560-650 m) of the active tongue (Fig. 3). New holes with steep walls formed as a result of the collapsing of the roofs of intra- or subglacial river channels, 5-15 $\mathrm{m}$ deep and up to $100 \mathrm{~m}$ long across the glacier. These collapse holes are situated at approximately 614-624 and 704-709 m a.s.l. along the profile from Figure 3.

In the same period, the decrease in the surface area of Dryadbreen took place mainly in its highest and lowest parts. First of all, its edges, exposed to the east, west, northeast and northwest at $\sim 600-950 \mathrm{~m}$ a.s.l., underwent recession (Figs 1 and 6). The glacier thickness did not change in the accumulation zone above $750 \mathrm{~m}$ but decreased by $20-25 \mathrm{~m}$ in the upper part of the glacier tongue at $630-750 \mathrm{~m}$. However, the tongue thickened by $10-35 \mathrm{~m}$ between 480 and $540 \mathrm{~m}$ on the investigated profile line and not at the edges. The stagnant and probably dead part of the tongue below $480 \mathrm{~m}$ underwent thinning (Fig. 3). The collapse hole, very similar in form and genesis to those in Håbergbreen, originated near the northwestern edge of the glacier at $\sim 620$ m a.s.l.

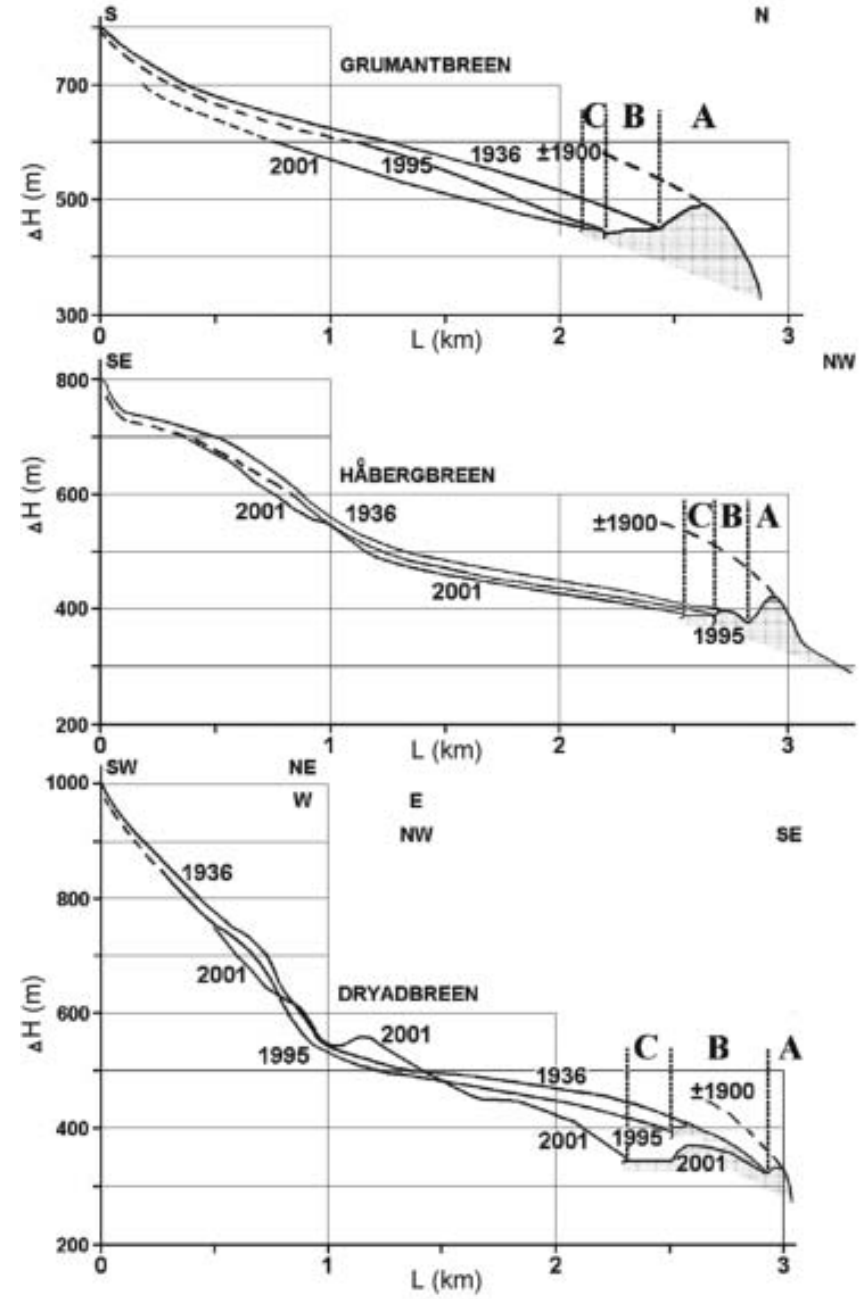

Fig. 3. Change of thickness and extent of the three glaciers: front ice-cored moraines formed between the end of the LIA and 1936 (A); from 1936 to 1995 (B); and from 1995 to 2001 (C) (profile lines shown in Fig. 1).

A characteristic feature of the recession of Håbergbreen and Dryadbreen was the lowering in altitude of the extent of their old, already dead fronts, which were not covered by debris (the fronts reached further downhill). This was due to ablation of dead ice in the lowest parts of their tongues. The Dryadbreen front moved downhill by $15 \mathrm{~m}$, reaching 360 m a.s.l. in 1995 and $345 \mathrm{~m}$ in 2001. The Håbergbreen

Table 1. Changes in area of the glaciers under study

\begin{tabular}{lccc}
\hline Area & Grumantbreen & Håbergbreen & Dryadbreen \\
\hline $1936^{*}\left(\mathrm{~km}^{2}\right)$ & $2.85(3.12)$ & $3.50(3.67)$ & $2.15(2.50)$ \\
$1995\left(\mathrm{~km}^{2}\right)$ & 1.94 & 2.14 & 1.45 \\
Decrease 1936-95 $\left(\mathrm{km}^{2}\right)$ & 0.91 & 1.36 & 0.70 \\
Decrease 1936-95 $(\%)$ & 32 & 39 & 32.5 \\
2001 $\left(\mathrm{km}^{2}\right)$ & 1.565 & 1.515 & 1.075 \\
Decrease 1995-2001 $\left(\mathrm{km}^{2}\right)$ & 0.375 & 0.625 & 0.375 \\
Decrease 1995-2001 $(\%)$ & 19 & 29 & 2.97 \\
Decrease 1936-2001 $\left(\mathrm{km}^{2}\right)$ & 1.285 & 1.985 & 26 \\
Decrease 1936-2001 $(\%)$ & 45.1 & 56.7 & 1.35 \\
& & & 25 \\
\end{tabular}

*Hagen and others (1993). The author's measurement is in parentheses. 


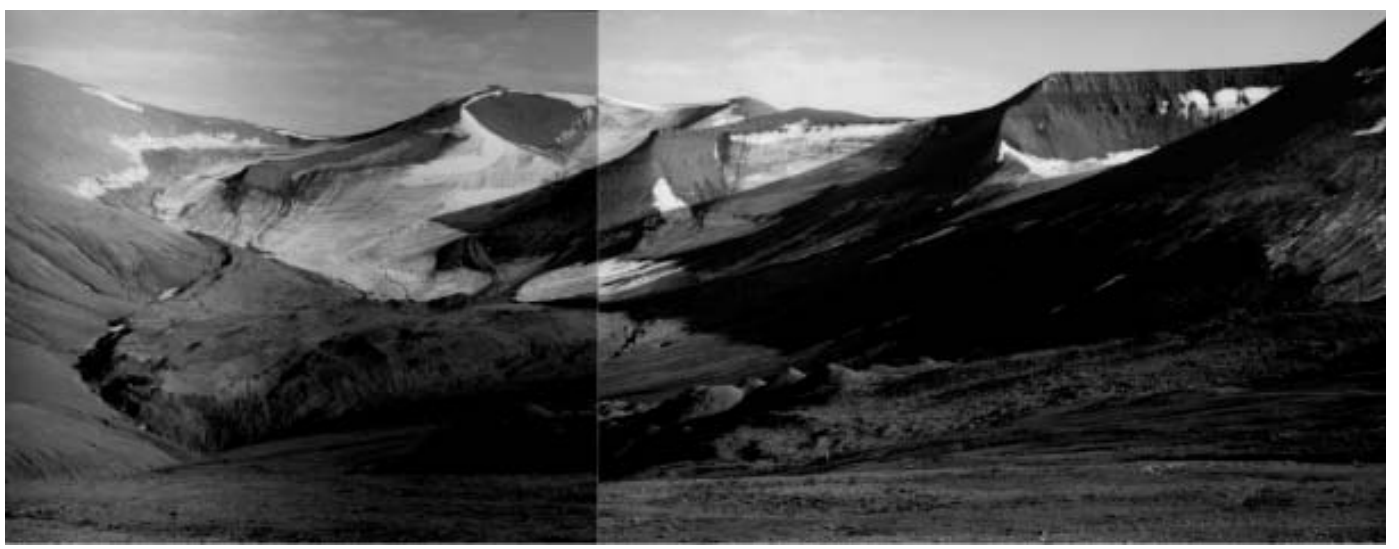

Fig. 4. Central part of the northern slope of the Lindströmfjellet-Håbergnuten ridge in 2001. Photograph looking east-southeast shows fragmentation of the former Håbergbreen glacier and formation of the extensive marginal zone which consists mainly of ice-cored moraines, as a result of glacial recession from 1936 to 2001.

front reached down to $400 \mathrm{~m}$ a.s.I. in 1995 and $390 \mathrm{~m}$ in 2001. Extensive areas of the 20th-century ice-cored moraines of both glaciers were completely reshaped after 1995 due to fast melting of dead ice and the collapse of old glacial channels. For example, the top of the ice-cored moraine of Håbergbreen dropped from 430 ma.s.l. in 1995 to 408$410 \mathrm{~m}$ in 2001. The new marginal lake, the only lake in the study area, originated at the front of this glacier after 1995.

The area of Grumantbreen decreased regularly from each side. The glacier thinned by a maximum of $40-50 \mathrm{~m}$ in its middle part from 1995 to 2001 (Figs 1, 3 and 7) The steep rocky outcrop west of the profile in Figure 3 was uncovered due to the thinning of the glacier at 675-700 ma.s.l. in this period. However, none of the river channels in the glacier collapsed. The glacier front was comparatively stable, having retreated slightly, reaching down to 400-450 m a.s.I. in 2001.

Håbergbreen, the largest of the glaciers until 1995, underwent the most intensive recession at the end of the 20th century. Its area decreased by $29 \%$ (Table 1), despite its northern exposure and the shadow of nearby mountains. This intense recession occurred due to the relatively low altitude of the middle part of the Lindströmfjellet-Håbergnuten mountain ridge, and thus a shorter slope of the glacier

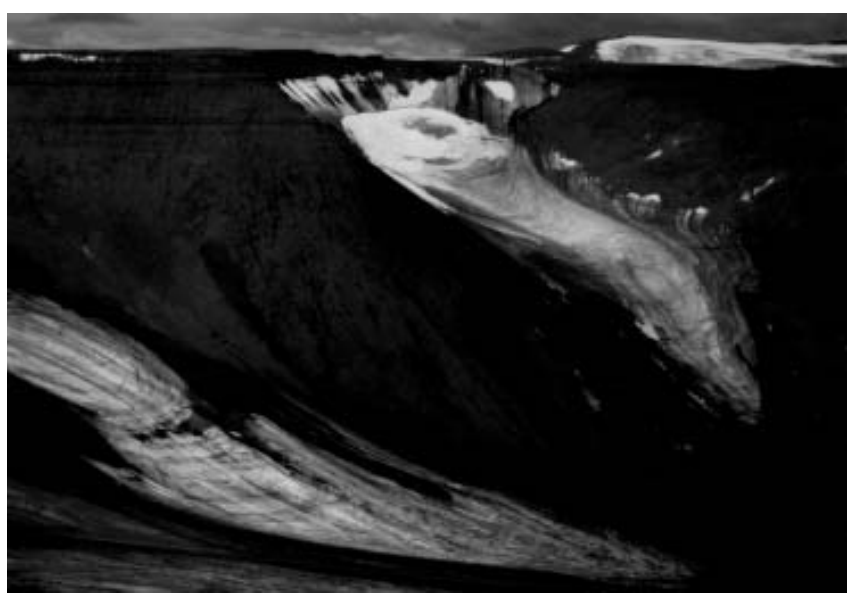

Fig. 5. The westernmost part of the former Håbergbreen glacier in 2001, diminishing because of the rising ELA above it. Photo looking southwest. surface from its front to the uppermost parts (compared to the other two glaciers). This part of the ridge barely reached the ELA after its 20th-century rise.

The 20th-century recession of Grumantbreen was the slightest of the three glaciers, especially between 1995 and 2001 when its area decreased by only 19\% (Table 1). The high altitude of $966 \mathrm{~m}$ (Lindströmfjellet) and maximum shading of its accumulation zone from nearby mountains enabled this glacier to be better preserved than the two others in 2001.

The 20th-century recession of Dryadbreen was close to the average value for the three glaciers (Table 1). The accumulation zone of Dryadbreen is the highest (Håbergnuten, up to $1031 \mathrm{~m}$ ) but the smallest, and reduced significantly due to minor shading.

The manner and rate of the recession of the glaciers under study were similar to those of the majority of other mountain glaciers in their neighbourhood (e.g. nearby Longyearbreen (Hagen, 1996)). Increased rates of recession in 1985-2000 (compared to 1936-85) were observed by Lankauf (2002) in the valley glaciers on Kaffiøyra, $\sim 100 \mathrm{~km}$ northwest of the study area.

\section{CONCLUSIONS}

There were two important manifestations of the recession of the three glaciers described. The retreating glaciers left bedrock exposures without morainic cover in the upper or steeper mountain slopes. Moving glacier tongues were transformed on their fronts and sides into motionless icecored moraines in valley bottoms. These moraines are usually separated from the glaciers by depressions. The surface of the glaciers is clean, not debris-covered, in the upper active parts and in motionless tongues which have not yet transformed into ice-cored moraines. The glaciers did not change into rock glaciers, probably due to the slowness of the slope processes above them. This type of recession is common in Nordenskiöld Land (Tolgensbakk and others, 2001).

Mountain glaciers in Nordenskiöld Land lost $\sim 60 \%$ of their volume between 1901 and 1976, and their surface areas decreased by $\sim 12 \%$ from 1912 to 1936 and by $4 \%$ from 1936 to 1966 (Koryakin, 1985). Afterwards the recession became much more rapid, which may be connected to the climate warming since the 1970s (Fig. 2). 


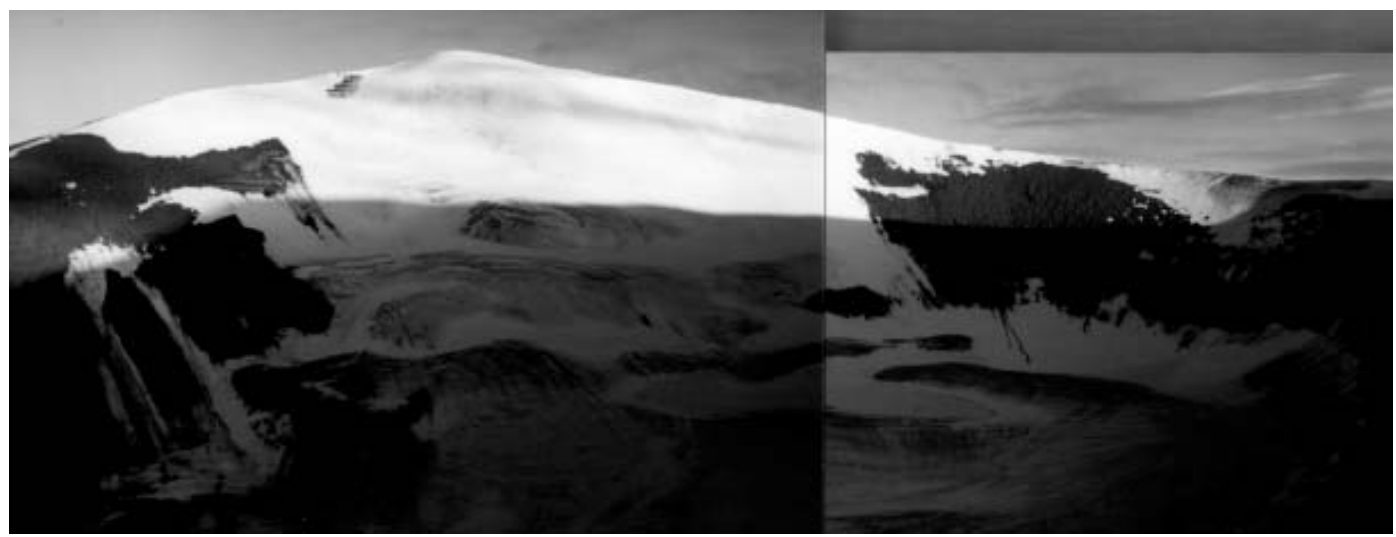

Fig. 6. The highest part of Dryadbreen, up to 1031 m a.s.l., with a northern exposure is still (2001) active despite a large reduction of lateral extents in the period 1995-2001. Photo looking south-southwest.

After 1990 the glaciers' rate of recession increased by at least a few times. This strongly intensified recession is probably due to both a noticeable temperature increase in the 1990s and a positive feedback initiated by all the climate warming and glacial recession after the LIA. The 20thcentury decrease in the surface and volume of the glaciers causes accelerated recession, intensified in the period of the slight but clear warming in the 1990s.

The glaciers described are not in a state of balance. They did not thaw enough in relation to the warming and the rise of the ELA (by at least 250-300 m since the beginning of the 20th century) because the summer seasons (though lengthened) are too short. The ELA continued to rise due to the airtemperature increase. A possible increase in precipitation was too small to significantly slow down this rise, which confirms results obtained by J. Kohler and others (unpublished information). Hence, the prognosis for the future response of the glaciers (for the next few decades) to the further slight warming or even stabilization of climate is straightforward. The lowest Håbergbreen glacier, already transformed into four ice patches, will disappear. Only its highest easternmost part may remain as a glacieret. Grumantbreen and Dryadbreen will survive as very small mountain glaciers in their uppermost parts only. However, this prognosis assumes that there will be no significant increase in winter snow precipitation that could enlarge the mass of the glaciers.

The landscape type of the upper slopes of the Nordenskiöld Land mountains is now in the final stage of transformation from a predominantly glacierized landscape to a partly unglacierized one.

\section{ACKNOWLEDGEMENTS}

Thanks to the referees, F. Navarro and R. Schütt, for improving the paper, and to E. Giles for assistance with copyediting. Thanks also to W. Brzozowski for help in field investigations of Dryadbreen, and to M. Jodlowski and T. Zapala for computer-elaborating the figures. Field investigations were financed by Norges Forskningsråd in 1995 and the Polish Committee for Scientific Research in 2001 (project No. 6P04G05418). Norsk Polarinstitutt provided logistic-scientific support. Numerical data on mean annual temperatures at Svalbard Airport were delivered by the Norwegian Meteorological Institute.

\section{REFERENCES}

Brázdil, R. 1988. Variation of air temperature and atmospheric precipitation in the region of Svalbard. In Brázdil, R. and 9 others, eds. Results of investigations of the geographical research expedition Spitsbergen 1985. Brno, Univerzita J.E. Purkyne v Brne, 285-323. (Folia Fac. Sci Geographia 24.)

Førland, E.J., I. Hanssen-Bauer and P.Ø. Nordli. 1997. Climate statistics and longterm series of temperature and precipitation at Svalbard and Jan Mayen. DNMI Rapp. 21/97.

Hagen, J.O. 1996. Svalbard. In Jania, J. and J.O. Hagen, eds. Mass balance of Arctic glaciers. Sosnowiec/Oslo, International Arctic Science Committee. Working Group on Arctic Glaciology, 30-38. (IASC Report 5.)

Hagen, J.O., O. Liestøl, E. Roland and T. Jørgensen. 1993. Glacier atlas of Svalbard and Jan Mayen. Norsk Polarinst. Medd. 129.

Hanssen-Bauer, I., M.K. Solås and E.L. Steffensen. 1990. The climate of Spitsbergen. DNMI Rapp. 39/90.

Koryakin, V.S. 1985. Kolebaniya i rezkiye podvizhki lednikov [Fluctuations and surges of glaciers]. In Kotlyakov, V.M., ed. Glyatsiologiya Shpitsbergena [Glaciology of Spitsbergen]. Moscow, Nauka. Akademiia Nauk SSSR, 80-93.

Lankauf, K.R. 2002. Recesja lodowców rejonu Kaffiøyry (Ziemi Oskara II -Spitsbergen) w XX wieku [The retreat of the glaciers in the Kaffiøyra region (Oscar II Land - Spitsbergen) in the 20th century]. Polska Akademia Nauk, Instytut Geografii i Przestrzennego Zagospodarowania, Geographical Studies 183, 1-221.

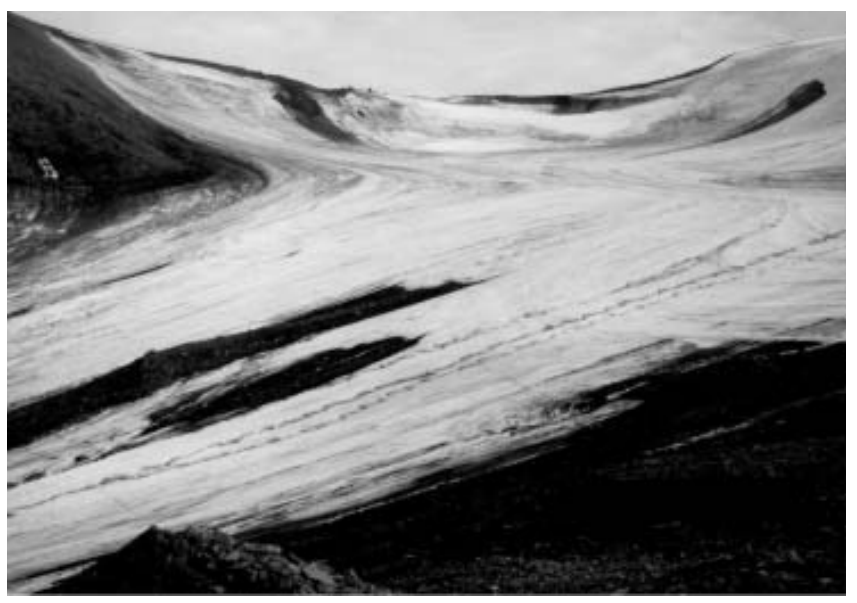

Fig. 7. Grumantbreen (2001) with steep rocky outcrops uncovered due to thinning in its upper part. Photo looking south. 
Leonard, K.C. and A.G. Fountain. 2003. Map-based methods for estimating glacier equilibrium-line altitudes. J. Glaciol., 49(166), 329-336.

Nordli, P.Ø. 1990. Temperature and precipitation series at Norwegian Arctic meteorological stations. DNMI Rapp. 40/90.

Sørbel, L., J. Tolgensbakk, J.O. Hagen and K. Høgvard. 2001. Geomorphological and Quaternary geological map, Svalbard 1:100,000. Sheet C9G Adventdalen. Norsk Polarinstitutt Temakart 31/32, 57-78.
Statistics Norway. 2001. Svalbard Airport 1988-2000. In Svalbard Statistics 2001. Oslo-Kongsvinger, Statistisk sentralbyrå, table 18.

Tolgensbakk, J., L. Sørbel and K. Høgvard. 2001. Geomorphological and Quaternary geological map, Svalbard 1:100,000. Spitsbergen Sheet C9G. Norsk Polarinstitutt Temakart 31/32.

Ziaja, W. 2001. Glacial recession in Sørkappland and central Nordenskiöldland, Spitsbergen, Svalbard, during the 20th Century. Arct. Antarct. Alp. Res., 33(1), 36-41. 